\title{
The Nexus between Finance, Growth and Poverty in India:
}

\section{The Cointegration and Causality Approach}

\author{
Rudra P. Pradhan \\ Vinod Gupta School of Management \\ Indian Institute of Technology Kharagpur, India \\ E-mail: rudrap@vgsom.iitkgp.ernet.in
}

\begin{abstract}
The paper examines the causal nexus between financial development, economic growth and poverty reduction in India during 1951-2008. The empirical analysis is based on cointegration and causality test. The cointegration test finds the presence of long run equilibrium relationship between financial development, economic growth and poverty reduction. The Granger causality test at the end confirms the presence of unidirectional causality from poverty reduction to economic growth, economic growth to finance development, financial development to poverty reduction and economic growth to poverty reduction. It also finds no causality between finance development and economic growth, and poverty reduction and finance development. The paper suggests that economic growth is considered as the policy variable to accelerate finance development and both could be used as the policy variable to reduce poverty in the economy.
\end{abstract}

Keywords: Financial development, Economic growth, Poverty reduction

\section{Introduction}

It is well recognized that financial development constitutes a potentially important mechanism for long run economic growth (Goodhart, 2004; Levine, 2003; Beck et al., 2001). It is, however, debated since the seminal work of Schumpeter (1911). The debate is basically on the direction of causality between finance development and economic growth. To date, there is no universal conclusion but the clarity on this issue is very crucial because it has significantly different implications for development policy. The literature ensures that an efficient financial system certainly encourage investment by identifying and funding adequate business opportunities, mobilizing savings, diversifying and reducing risks, facilitating exchange of goods and services, and so forth. The system certainly helps enhancing optimal allocation of resources and hence, contributes to economic growth in the development process. It is, however, hypothesized, that finance-growth nexus could have considerable effect on poverty reduction. The literature provides extensive work on finance-growth nexus. But very few studies have gone the full distance to examine the nexus between financial development and poverty reduction on the one hand and economic growth and poverty reduction on the other, except the work by Odhiambo (2009).

The objective of this paper is to examine the causal relationship between financial development, economic growth and poverty reduction in India, using cointegration and causality approach. The reminder of the paper is organized as follows. Section II provides brief status of India, particularly with reference to financial sector development, economic growth and poverty alleviation. Section III presents literature review. Section IV presents the methodology and database. Section $\mathrm{V}$ discusses the empirical results. And the final section provides conclusion and Policy Implication.

\section{Financial Development, Economic Growth and Poverty Alleviation in India}

India, the second most populated country of above 1.3 billion, has emerged as one of the fastest growing economies and ten most emerging industrialized nations in the world. With the GDP growth of $7.5 \%$ per annum, India stands second after China. Its current per capita GDP is about US\$ 1154 and is recognized as fourth largest economy in terms of PPP. The country is now very popular for its rapidly growing consumer market and financial market and has developed as one of the largest cost competitiveness technical workforce nation with large pool of skilled manpower like manager, engineer, etc. Its comparative advantage in the world market has drastically changed because of various factors like high economic growth, financial sectors development and changing technology. On the contrary, India is also low performer in various other aspects like poverty alleviation, regional disparities, public delivery, accountability and infrastructural deficiency. The paper is, 
moreover, very keen on the status of financial sector development, economic growth and poverty alleviation, and their causal relationship in the long run.

India's financial system comprises Reserve Bank of India (an apex of financial sector), commercial banks (public sector, private sector, foreign banks and cooperative institutions), financial institutions (AIFIS, SFCS, \& SIDCS), non-banking financial companies and capital market intermediaries. About $92 \%$ of the banking is under government control, while the rest comprises private and foreign banks. To date, India has about 296 banks, of which 39 are foreign banks. The overall efficiency of the banking sector could be recognized by the index of financial deepening, defined as the ratio of total bank deposits to GDP. The index is substantially increasing over the years (see Figure 1). The magnitude of the overall status of India's financial system could be understood better by looking the trends of the other financial parameters such as money supply, capitalization rate, reserve ratio, etc. The overall trends of India's financial sector is somewhat encouraging, especially after the globalization era of 1990s. However, the status is not up to the mark as per the standard of the developed countries. This is basically because of two reasons: first, structural weakness of the real sector and lack of competitiveness in the international markets; second, the underdeveloped credit delivery systems that fail to respond the dynamic socio-economic environment.

Despite the substantial growth in India's financial sector, the trend of economic growth is by and large mixed. The growth rate is about $4.8 \%$ in 1951-52 and decelerated during the fifties and sixties to reach a low of less than $3.2 \%$ during 1971-72 (Virmani, 2004). The trend growth rate was accelerated from the mid seventies to reach a pack of almost $6.2 \%$ per annum during 1994-95. The trend was slightly decelerated to $3.8 \%$ in 2002 and then increased to $9.7 \%$ in 2006-07(see Figure 2). However, the year 2009 saw a significant slowdown in India's GDP growth rate to $6.7 \%$ (GOI, 2008-09). This is probably due to global financial crisis in 2007- 2008. The deceleration of growth in 2008-09 was spread across all sectors except mining, quarrying, community, social and personal services. This could be concluded that the performance of economic growth depends upon the growth of financial sectors in the economy. However, despite the high level of real and financial sector development, the magnitude of poverty alleviation in India has been very low. The rate of poverty was about $47 \%$ in 1951 and increased to a peak of $64 \%$ in 1954 . The rate was declined to $45 \%$ in 1960 and then increased to $64 \%$ in 1966 . The rate of poverty was further declined to $34 \%$ in 1989 and then increased to $43 \%$ in 1992. It was again went down to low of $36 \%$ in 1995 and then increased to $43 \%$ in 1998 (Figure 3). The current status of poverty in India is about $26 \%$ and $21.8 \%$ in 1999 and 2008 respectively (CIA, 2009).

\section{Literature Review}

Financial development is a multidimensional concept and comprises a potentially important mechanism for long run economic growth. There are numerous studies that support the relationship between financial development and economic growth, both theoretically and empirically (Abu-Bader and Abu-Qarn, 2008; Demetriades and Andrianova, 2004; Godhart, 2004; Levine, 2003; Beck et al., 2000; Von Furstenberg and Fratianni, 1996; King and Levine, 1993). The theoretical underpinnings of this relationship can be traced back to the work of Schumpeter (1911) and more recently, to McKinnon (1973), Shaw (1973) and their disciples (Mathieson, 1980; Fry, 1978; Galbis, 1977; Kapur, 1993). The empirical evidence, including firm-level analysis, industry-level analysis, individual country analysis and broad cross-country comparison, suggests that there is a significant positive association between financial development and economic growth. In other words, financial development is very essential and prime requirement for economic growth. The lack of same not only affects economic growth but also affect other socio-economic development in the economy.

However, these findings do not establish the direction of causality between the two. In fact, in the past three decades, there are copious studies that have examined the causal relationship between financial development and long run economic growth. But these empirical findings present conflicting views, particularly with respect to the direction of causality. That means they may/ may not cause each other. On the one side, financial development is caused by long run economic growth when real growth has been taken place so that the expansion of financial institutions is only a result of the need of the expansion of the real economic activities (see Demetriades and Hussein, 1996). On the other side, the expansion of financial institutions can foster economic growth by increasing savings and borrowing options and the reallocation of capital (Beck et al., 2000; $\mathrm{Xu}, 2000$; Levine et al., 2000; Neusser and Kugler, 1998; Levine, 1997). Therefore, the conflict is due to presence/ absence of unidirectional/ bidirectional causality between financial development and economic growth (see Calderon and Liu, 2003; Levine, 2003; Luintel and Khan, 1999; Berthelemy and Varoudakis, 1996; Greenwood and Bruce, 1997; Lucas, 1988). In summary, the literature 'with reference to direction of causality between financial development and economic growth' provides three conflicting views: supply leading response (financial development to economic growth), demand- following response (economic growth to finance 
development) and feedback response (bidirectional causality between finance development and economic growth).

However, very few studies have gone beyond the link on poverty reduction. The relationship between financial development, economic growth and poverty reduction is, in fact, very important for policy goals, particularly in the country like India. This is because both finance development and economic growth have direct and indirect contribution to poverty reduction in the economy. There are number of ways we can justify the same. First, with the basis of market failures like information asymmetry and high fixed cost of lending to small borrowers, financial development can enhance the opportunities for the poor to access the formal finance (Stiglitz, 1998; Jalilian and Kirtpatrick, 2001). Second, sound financial system encourages the poor to access finance, particularly by credit and insurance risk services, and thereby, strengthening the productive assets of the poor, enhancing their productivity and increasing their potential for achieving sustainable livelihoods (World Bank, 2001). The financial sector also enables the poor to draw down accumulated savings or borrow money to start micro-enterprises. This eventually leads to wider access to finance, employment and income, and thus, contributes poverty reduction (DFID, 2004).

Above all, the direct link between financial development and poverty alleviation emanates from the availability of accessible financial instruments, services and institutions for poor the households. Financial development can also indirectly contribute to poverty reduction in the developing countries, particularly through its impact on economic growth. In most of the cases, the debate on the role of financial development has mainly concentrated on its link with economic growth. The hypothesis here is that once economic growth has been achieved it would unambiguously lead to poverty alleviation. But in reality, economic growth may not be a sufficient condition for poverty alleviation. For instance, if finance development increases income inequality, then the country can enjoy positive economic growth without any benefit to its poorest households. In this process, high income group will be richer, while the low income group will be poorer.

On the empirical front, we have two different empirical analysis: first, on the relationship between financial development and poverty reduction (see Jalilian and Krkpatrick, 2005; Jeanneney and Kpodar, 2005; Quartey, 2005; Honohan, 2004; Beck et al., 2001; Banerjee and Newman, 1993; Clarke et al., 2002); second, on the relationship between economic growth and poverty reduction (see De Janvry and Sadoulet, 2000; Eastwood and Lipton, 2001). In most of the cases, finance development is pro-poor. The financial instability specifically hurts the poor and dampens its positive effects on poverty reduction. On the negative side, if the financial development leads to growing income inequality, in increases the volume of poverty in the economy (Honohan, 2004; Beck et al., 2004). So the heart of this paper is to link the financial development with poverty reduction in the Indian economy by using the cointegration and causality approach. The detail descriptions of these techniques are explained below.

\section{Econometric Methodology}

The study deploys dynamic Granger causality test to trace the nexus between finance development, economic growth and poverty reduction in India. The model is used for the same is as follows:

$$
\begin{aligned}
& P_{C G D P_{t}}=\eta_{0}+\sum_{i=1}^{n} \alpha_{1 i} P C G D P_{t-i}+\sum_{i=1}^{n} \alpha_{2 i} F D_{t-i}+\sum_{i=1}^{n} \alpha_{3 i} P O V_{t-i}+\alpha_{4} E C T_{t-1}+\zeta_{t} \\
& F D_{t}=\eta_{1}+\sum_{i=1}^{n} \beta_{1 i} P C G D P_{t-i}+\sum_{i=1}^{n} \beta_{2 i} F D_{t-i}+\sum_{i=1}^{n} \beta_{3 i} P O V_{t-i}+\beta_{4} E C T_{t-1}+\xi_{t} \\
& P O V_{t}=\eta_{2}+\sum_{i=1}^{n} \delta_{1 i} P C G D P_{t-i}+\sum_{i=1}^{n} \delta_{2 i} F D_{t-i}+\sum_{i=1}^{n} \delta_{3 i} P O V_{t-i}+\delta_{4} E C T_{t-1}+\varepsilon_{t}
\end{aligned}
$$

Where, PCGDP is economic growth; FD is finance development; POV is poverty reduction; ECT is error correct term; $\varepsilon, \zeta$ and $\xi$ are mutually uncorrelated white noise residuals. The corresponding casual flows and their respective null hypothesis are given below:

1. For $\mathrm{FD}=>\mathrm{POV}, \delta_{2 \mathrm{i}} \neq 0$ and $\delta_{4} \neq 0$

2. $\quad$ For $\mathrm{POV}=>\mathrm{FD}, \beta_{3 \mathrm{i}} \neq 0$ and $\beta_{4} \neq 0$ 
3. For PCGDP $\Rightarrow$ POV,$\delta_{1 \mathrm{i}} \neq 0$ and $\delta_{4} \neq 0$

4. For POV $\Rightarrow$ PCGDP, $\alpha_{3 \mathrm{i}} \neq 0$ and $\alpha_{4} \neq 0$

5. For FD $\Rightarrow>$ PCGDP, $\alpha_{2 \mathrm{i}} \neq 0$ and $\alpha_{4} \neq 0$

6. For PCGDP $=>F D, \beta_{1 \mathrm{i}} \neq 0$ and $\beta_{4} \neq 0$

However, the first and foremost condition of this above model is to test the stationarity of variables and their cointegration. The Augmented Dickey Fuller (ADF; Dickey and Fuller, 1981) and Phillips and Perron (PP; Phillips and Perron, 1988) tests have been used to examine the stationarity. The modelling procedure of these two tests is described as follows:

$$
\Delta Y_{t}=\alpha_{1}+\alpha_{2} Y_{t-1}+\sum_{i=1}^{p} \beta_{i} \Delta Y_{t-i}+\varepsilon_{t}
$$

Where $\mathrm{Y}$ is the variable of choice; $\Delta$ is the first- difference operator; and $\varepsilon_{t}$ is a stationary stochastic process. To determine the order of integration of a particular time series variable, the equation has to be modified by including second differences on lagged first and $p$ lags of second differences. This is as follows:

$$
\Delta^{2} Y_{t}=\eta_{2} \Delta Y_{t-1}+\sum_{i=1}^{p} \mu_{i} \Delta^{2} Y_{t-i}+\xi_{t}
$$

The stationarity of ADF test and PP test are applied to equations 4 and 5 respectively. The null hypotheses are $\mathrm{H}_{0}$ : $\alpha_{2}=0$ against $\mathrm{H}_{0}: \alpha_{2} \neq 0$ for equation 4 and $\mathrm{H}_{0}: \eta_{2}=0$ against $\mathrm{H}_{0}: \eta_{2} \neq 0$ for equation 5 correspondingly.

The Johansen and Juselius (JJ; Johansen and Juselius, 1990) test, on the contrary, is deployed to test the cointegration between finance development, economic growth and poverty reduction. The modelling of this test is described in the below.

Consider a Vector Auto Regressive (VAR) model of order k:

$$
\Delta Y_{t}=\mu+\Gamma_{1} Y_{t-1}+\Gamma_{2} X_{t-2}+\ldots+\Gamma_{k-1} X_{t-k+1}+\prod Y_{t-k}+\zeta_{t}
$$

Where, $\mathrm{Y}_{\mathrm{t}}$ is $3 \mathrm{X} 1$ vector of the first order integrated [i.e., I (1)] variables; $\Gamma_{\mathrm{i}}$ are $3 \mathrm{X} 3$ coefficient matrices; $\zeta_{\mathrm{t}}$ is a vector of normally and independently distributed error terms. The existence of cointegrating vectors (r) implies $\Pi$ is rank-deficient. The maximal eigen value and trace statistic tests derived by Johansen (1991) for identifying the number of distinct cointegrating vectors in the VAR are well known. If $\Pi$ is of rank $\mathrm{r}(0<\mathrm{r}<3)$, then it can be decomposed as: $\Pi=\alpha \beta^{\prime}$, where $\alpha(3 \mathrm{Xr})$ and $\beta(3 \mathrm{Xr})$; and the equation (6) can be rewritten as:

$$
\Delta Y_{t}=\mu+\Gamma_{1} Y_{t-1}+\Gamma_{2} X_{t-2}+\ldots+\Gamma_{k-1} X_{t-k+1}+\alpha\left(\beta^{\prime} Y_{t-k}\right)+\zeta_{t}
$$

The rows of $\beta$ are interpreted as the distinct cointegrating vectors whereby $\beta^{\prime} Y_{t-k}$ from linear stationary processes. The $\alpha$ 's are the error correction coefficients (loading factors) that indicates the speed of adjustment towards the long run equilibrium. In equation (4), $\beta$ vector is unrestricted. Unless there is a unique cointegrating vector (i.e. $r=1$ ), the matrix of cointegrating vectors, as it stands, cannot be identified as typical long run economic relationships. This is because any linear combination of cointegrating vectors forms another linear stationary relationship. Hence, the VAR can also be rewritten as

$$
\Delta Y_{t}=\mu+\prod Y_{t-p}+\sum_{i=1}^{k-1} A_{i} \Delta Y_{t-i}+\varepsilon_{t}
$$

From the residual vectors, we construct two likelihood ratio test statistics. The first test statistics is trace test, which is represented as follows:

$$
\lambda_{\text {Tra }}=-T \sum_{i=r+1}^{n} \log \left(1-\hat{\lambda}_{i}\right)
$$


where $\hat{\lambda}_{r+1}, \ldots . . \hat{\lambda}_{n}$ are (n-r) smallest estimated eigenvalues. The null hypothesis is to test that there are at most $\mathrm{r}$ unique cointegration vectors. The second test statistics is the maximal eigenvalue test, which is represented by:

$$
\lambda_{\operatorname{Max}}=-T \log \left(1-\hat{\lambda}_{r+1}\right)
$$

The null hypothesis for this test is that there are $\mathrm{r}$ cointegrating vectors in $\mathrm{Y}_{\mathrm{t}}$. For both tests, the alternative hypothesis is that there are $g>r$ cointegration vectors in $Y_{t}$. Johansen and Juselius (1990) suggested that the trace test may lack power relative to the maximal eigenvalue test. However, the trace test is more robust to the non-normality of errors.

The data used under this study are annual time series data, which covers the period 1951- 2008. These are collected from various sources, namely Handbook of Statistics on Indian Economy, Reserve Bank of India, Mumbai; Economic Survey, Government of India, New Delhi; Central Statistical Organization, New Delhi; Dandge and Kadam, (2005); and Fan (1998).

\section{Empirical Results and Discussion}

To determine, whether there is nexus between finance development, economic growth and poverty reduction, we first test the stationarity and cointegration between them. The ADF and PP tests are applied at the level and first differences of the time series data. The estimated results are reported in Table 1. The results confirm that confirm that finance development (FD), measured by broad money supply to GDP, economic growth, measured by per capita GDP (PCGDP) and poverty reduction (POV), measured by the people below the poverty line, are stationary at the first difference and integrated of order one. The Johansen Maximum Likelihood test $\left(\lambda_{\operatorname{Tra}} \& \lambda_{\operatorname{Max}}\right)$ is used to ascertain whether or not the variables are cointegrated. This provides a unified framework for estimation and testing of cointegrating relations in context of a VAR error correction model.

The cointegration rank ' $r$ ' of the time series was tested using two test statistics. Denoting the number of cointegrating vectors by ' $r_{o}$ ', the maximum eigen value $\left(\lambda_{\operatorname{Max}}\right)$ test is calculated under the null hypothesis $r_{o}=r$ against an alternative hypothesis $r_{o}>r$. The trace test $\left(\lambda_{\text {Tra }}\right)$ is calculated under the null hypothesis that $r_{o} \geq r$ against $\mathrm{r}_{0}<\mathrm{r}$. The results of both the statistics are reported in Table 2. Both these two statistics rejected the null hypothesis of no cointegration at $1 \%$ level of significance (see Table 2). The results reassert the presence of one cointegrating vector between finance development, economic growth and poverty reduction. That means there is long run equilibrium relationship between finance development, economic growth and poverty reduction. This also indicates that there is the possibility of causality between them. The Granger causality test, based on Error Correction Model, is applied for the same. The summary of Granger causality test is reported in Table 3. The estimated results confirm the followings:

1. A unidirectional causality from poverty reduction to economic growth [POV $\Rightarrow>$ PCGDP], economic growth to finance development [PCGDP $=>$ FD], economic growth to poverty reduction [PCGDP $=>$ $\mathrm{POV}]$ and financial development to poverty reduction $[\mathrm{FD}=>\mathrm{POV}]$.

2. It also finds no causality between finance development and economic growth [FD $<\neq>$ PCGDP], and poverty reduction and finance development $[\mathrm{POV}<\neq>\mathrm{FD}]$.

\section{Conclusion and Policy Implications}

The main of this paper is to investigate the long run and short run dynamics between financial development, economic growth and poverty reduction in India over the period 1951-2008. Estimation process starts with examining stationarity property of the underlying time series data. The unit root test has been applied for the same. The estimated results confirmed that financial development, economic growth, and poverty reduction are stationary at the first differences. Hence, they are integrated of order one. We next examined the existence of cointegration among the stationary variables by using Johansen cointegration test. The estimated results declared that there is one cointegration and hence, confirmed the existence of long run equilibrium relationship between financial development, economic growth and poverty reduction.

The Granger- causality test finally confirmed the presence of the nexus between finance development, economic growth and poverty reduction in India during the period 1951-2008. It detects the unidirectional causality from poverty reduction to economic growth, economic growth to finance development, economic growth to poverty 
reduction, and financial development to poverty reduction. It also finds no causality between finance development and economic growth and poverty reduction to finance development.

To conclude, an enhanced economic growth is very responsible for financial development and both have substantial contribution to poverty reduction in the economy. The policy implication of this result is that economic growth is considered as the policy variable to accelerate finance development and both could be used as the policy variable for poverty reduction in the economy. Hence, to maintain sustainable economic growth and poverty reduction, government has to deepen the financial sector and undertake essential measures to strengthen the long run relationship between financial development and economic growth. The lack of same not only affects the finance-growth nexus but also overall poverty reduction in the country. Hence, government has to take the initiative with greater caution and bigger interest.

\section{References}

Abu-Bader, S. and Abu-Qarn, A. S. (2008). Financial Development and Economic Growth: The Egyptian Experience. Journal of Policy Modelling, 30 (5): 887-898.

Banerjee, A. and Newman, A. (1993). Occupational Choice and the Process of Development. Journal of Political Economy, 101: 274-298.

Beck, T., Demirguc-Kunt, A. and Levine, R. (2004). Finance, Inequality and Poverty: Cross Country Evidence. World Bank Policy Research Working Paper 3338, World Bank, Washington DC.

Beck, T., Levine, R. and Loayza, N. (2000). Finance and Source of Growth. Journal of Financial Economics, 58 (1-2): 261-300.

Berthelemy, J. C. and Varoudakis, A. (1996). Economic Growth, Convergence Clubs, and the Role of Financial Development. Oxford Economic Papers, 48 (2): 300-328.

Calderon, C. and Liu, L. (2003). The Direction of Causality between Financial Development and Economic Growth. Journal of Development Economics, 72: 321-334.

CIA. (2009). Central intelligence Agency, The World Fact Book, Washington DC.

Clarke, G., Xu, L. and Fou, H. F. (2002). Financial and Income Inequality: Test of Alternatives Theories. World Bank Policy Research Paper, WPS 2984, World Bank, Washington DC.

Dandge, R. G. And Kadam, S. (2005). Impact of Globalization on Poverty in India. Journal of Management and Social Sciences, 1: 80-84.

De Janvry, A. and Sadoulet, E. (2000). Growth, Poverty and Inequality in Latin America A Casual Analysis, 1970-1994. Review of Income and Wealth, 46: 267-287.

Demetriades, P. and Andrianova, S. (2004). Finance and Growth: What we Know and What We Need to Know, in Goodhart, C. A. E. (Ed.), Financial Development and Growth: Explaining the Links, Palgarve Macmillan, New Work.

Demetriades, P. and Hussein, K. (1996). Financial Development and Economic Growth: Cointegration and Causality Tests for 16 Countries. Journal of Development Economics, 51(2): 387-411.

DFID. (2004). Financial Sector Development: A pre-requisite for Growth and Poverty Reduction? Department for International Development (DFID), Policy Division.

Dickey, D. A. and Fuller, W. A. (1981). Likelihood Ratio Statistics for Autoregressive Time Series with a Unit Root. Econometrica, 49: 1057-1072.

Eastwood, R. And Lipton, M. (2001). Pro-poor Growth and Pro-Growth poverty Reduction: Meaning, Evidence and Policy Implications. Asian Development Review, 19: 1-37.

Fan, S., Hazell, P. and Thorat, S. (1998). Government Spending, Growth and Poverty: An Analysis of Interlinkages in Rural India. EPTD Discussion Paper No. 33, International Food Policy Research Institute, Washington, D.C.

Fry, M. J. (1978). Money and Capital or Financial Deepening in Economic Development. Journal of Money, Credit and Banking, 10 (4): 464-475.

Galbis, V. (1977). Financial Intermediation and Economic Growth in Less-Developed Countries: A Theoretical Approach. Journal of Development Studies, 13 (2): 58-72. 
Goodhart, C. A. E. (2004). Financial Development and Growth: Explaining the Links. Palgrave Macmillan, New York.

Granger, C. W. J. (1988). Some Recent Developments in a Concept of Causality. Journal of Econometrics, 39: 199-211.

Greenwood, J. and Bruce, S. (1997). Financial Markets in Development, and the Development of Financial Markets. Journal of Economic Dynamics and Control, 21 (2): 145-181.

Honohan, P. (2004). Finance Development, Growth and Poverty: How Close are the Links? In Goodhart, C. (ed.), Financial Development and Economic Growth: Explaining the Links. Palgrave Macmillan, Basingstoke.

Jalilian, H. and Kirkpatrick, C. (2002). Finance Development and Poverty Reduction in Developing Countries. International Journal of Finance and Economics, 7: 97-108.

Jalilian, H. and Kirkpatrick, C. (2005). Does Financial Development Contribute to Poverty Reduction. Journal of Development Studies, 41: 636-656.

Jeanneney, S. G. and Kpodar, K. (2005). Finance Development, Finance Instability and Poverty, CASE WPS/2005-09. University of Auvergne.

Johansen, S. (1991). Estimation and Hypothesis Testing of Cointegration Vectors in Gaussian Vector Autoregressive Models. Econometrica, 59: 1551-1580.

Johansen, S. and Juselius, K. (1990). Maximum Likelihood Estimation and Inference on Cointegration with Application to the Demand for Money. Oxford Bulletin of Economics and Statistics, 52: 169-210.

Kapur, B. K. (1993). Alternative Stabilization Policies for Less Developed Countries. Journal of Political Economy, 84: 777-795.

King, R. G. and Levine, R. (2003). Finance and Growth: Schumpeter might be Right? Quarterly Journal of Economics, 108 (3): 717-737.

Levine, R. (1997). Financial Development and Economic Growth: Views and Agenda. Journal of Economic Literature, 35 (2): 688-726.

Levine, R. (2003). More on Finance and Growth: More Finance, More Growth? Federal Reserve Bank of St. Louis Review, 85 (4): 31-46.

Levine, R., Loayza, N. and Beck, T. (2000). Financial Intermediation and Growth: Causality Analysis and Causes. Journal of Monetary Economics. 46 (1): 31-77.

Lucas, R. (1988). On the mechanics of Economic Development. Journal of Monetary Economics, 22 (1): 3-42.

Luintel, K. and Khan, M. (1999). A Quantitative Reassessment of the Finance-Growth Nexus: Evidence from a Multivariate VAR. Journal of Development Economics, 60 (2): 381-405.

Mathieson, D. J. (1980). Financial Reform and Stabilization Policy in a Developing Economy. Journal of Development Economics, 7 (3): 359-395.

McKinnon, R. (1973). Money and Capital in Economic Development. The Brooking Institution, Washington DC.

Neusser, K. and Kugler, M. (1998). Manufacturing Growth and Financial Development: Evidence from OECD Countries. Review of Economics and Statistics, 80 (4): 638-646.

Odhiambo, N. M. (2009). Finance-Growth-Poverty Nexus in South Africa: A Dynamic Causality Linkage. Journal of Socio-Economics, 38: 320-325.

Phillips, P. C. B. and Perron, P. (1988). Testing for a Unit Root in Time Series Regression. Biometrica, 75: 335-346.

Quartey, P. (2005). Financial Sector Development, Savings Mobilisation and Poverty Reduction in Ghanna, UNU-WIDER 2005, Research Paper No. 2005/71, United Nations University, Helsinki, Finland.

Schumpeter, J. A. (1911). The Theory of Economic Development. Harvard University Press, Cambridge, MA.

Shaw, E. (1973). Financial Deepening in Economic Development. Oxford University Press, Oxford.

Stiglitz, J. (1998). The Role of the State in Financial Markets. In: Proceedings of the World Bank Annual Conference on Development Economics, pp. 19-52. 
Table 1. Unit Root Test Results

\begin{tabular}{|c|c|c|c|c|c|}
\hline & \multicolumn{2}{|c|}{ ADF Statistics } & \multicolumn{2}{|c|}{ PP Statistics } & \multirow[b]{2}{*}{ Conclusion } \\
\hline & LD & FD & LD & FD & \\
\hline PCGDP & 1.71 & $3.366^{*}$ & 1.399 & $-5.047^{*}$ & I [1] \\
\hline $\mathrm{M}_{2} /$ GDP & 2.70 & $2.947^{*}$ & -1.259 & $-8.478^{*}$ & I [1] \\
\hline POV & -0.79 & $-7.66^{*}$ & -0.790 & $-7.666 *$ & I [1] \\
\hline
\end{tabular}

Note 1: ADF: Augmented Dickey Fuller Test; PP: Phillips- Perron Test; LD: Level Data; FD: First Difference Data; I (1): Integrated of order one; *: Indicates Statistical Significance.

Table 2. Cointegration Results

\begin{tabular}{|c|c|c|c|c|c|}
\hline \multicolumn{2}{|c|}{ Hypothesized Cointegrating } & \multicolumn{3}{|c|}{ Test Statistics } & \multirow[b]{2}{*}{$\mathrm{CV}$} \\
\hline $\mathbf{H}_{\mathbf{0}}$ & $\mathbf{H}_{\mathbf{A}}$ & $\lambda-\operatorname{Max}$ & CV & $\lambda$ - Tra & \\
\hline $\mathbf{r}=\mathbf{0}$ & $\mathbf{r}>\mathbf{0}$ & $45.53^{*}$ & 42.92 & $28.15 *$ & 25.82 \\
\hline$r \leq 1$ & $r>1$ & 21.37 & 25.87 & 13.09 & 19.39 \\
\hline $\mathbf{r} \leq 2$ & $\mathbf{r}>\mathbf{2}$ & 13.94 & 12.52 & 8.29 & 12.52 \\
\hline
\end{tabular}

Note: $r$ indicates the number of cointegrating relationships; CV: Critical values; *: Indicates significance level.

Table 3. Causality Results

\begin{tabular}{|c|c|c|c|c|c|}
\hline \multirow{2}{*}{$\begin{array}{l}\text { Dependent } \\
\text { Variables }\end{array}$} & \multicolumn{2}{|c|}{ Short Run Causality } & \multicolumn{2}{|c|}{ Long Run Causality } & \multirow{2}{*}{$\begin{array}{l}\text { Joint Causality } \\
\text { F }\end{array}$} \\
\hline & $\triangle$ PCGDP & $\Delta \mathbf{M}_{2} / \mathbf{G D P}$ & POV & ECT (-1) & \\
\hline$\triangle$ PCGDP & -------- & 0.006 & $2.97 * *$ & 0.516 & $31.47^{*}$ \\
\hline$\Delta \mathbf{M}_{2} /$ GDP & $38.88^{*}$ & --------- & 0.032 & 2.290 & $62.62 *$ \\
\hline$\triangle \mathrm{POV}$ & $9.225^{*}$ & $15.51^{*}$ & ------- & -2.039 & $10.74^{*}$ \\
\hline
\end{tabular}

Note: *(**): Indicates statistically significant at $1 \%(5 \%)$ level. 


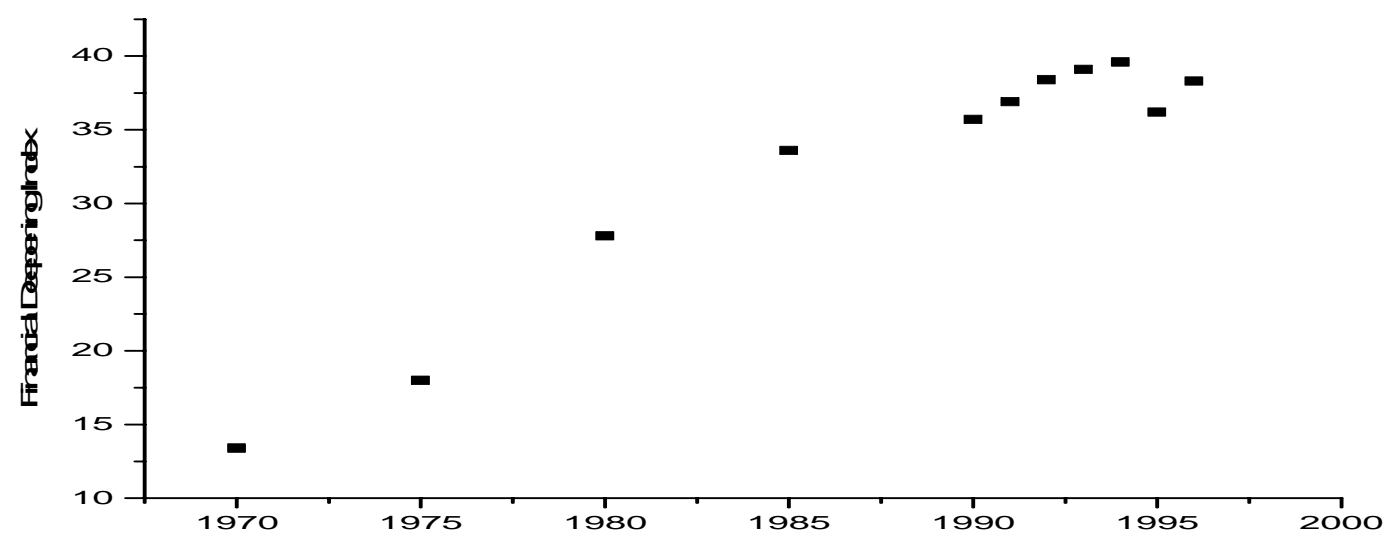

Figure 1. The Trends of Financial Deepening in India

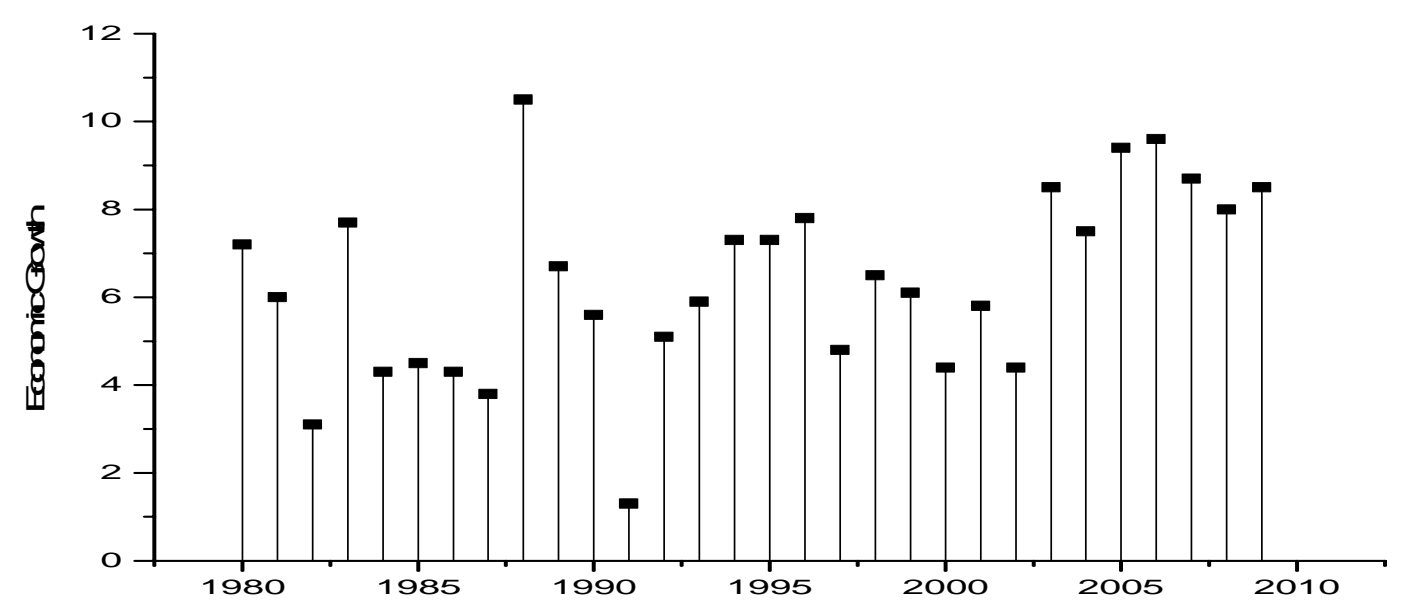

Figure 2. The Trends of PCGDP in India

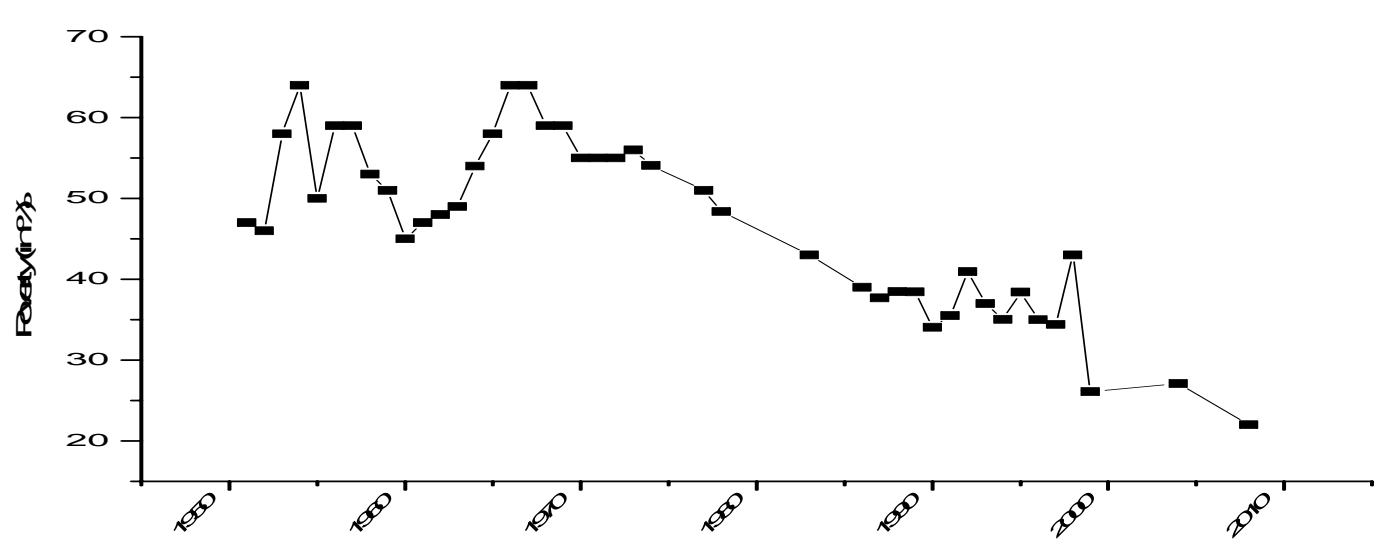

Figure 3. The Trends of Poverty in India 